\title{
Drift curves from spray applications on commom bean crop
}

\author{
Curvas de deriva de aplicações foliares na cultura do feijão
}

\author{
Mariana Rodrigues Bueno1*, João Paulo Arantes Rodrigues da Cunha', Denise Garcia de Santana ${ }^{1}$
}

\author{
1Universidade Federal de Uberlândia/UFU, Instituto de Ciências Agrárias/ICIAG, Uberlândia, MG, Brasil \\ *Corresponding author: marianarb_agro@yahoo.com.br \\ Received in April 23, 2016 and approved in September 2, 2016
}

\begin{abstract}
In order to avoid the occurrence of drift in pesticide applications, it is fundamental to know the behavior of sprayed droplets. This study aimed to determine drift curves in pesticide applications on common bean crop under brazilian weather conditions, using different nozzle types and compared them with the "German" and "Dutch" drift prediction models. The experiment was conducted in Uberlândia, Minas Gerais/Brazil, in completely randomized design with ten replications and $4 \times 20$ split-plot arrangement in space. Drift deposited on collectors located over ground level was resulted by $150 \mathrm{~L} \mathrm{ha}^{-1}$ carrier volume applications through four nozzle types (XR 11002 (fine droplets); AIXR 11002 (coarse droplets); TT 11002 (medium droplets); TTI 11002 (extremely coarse droplets)), collected in 20 downwind distances, parallel to the crop line outside the target area, spaced by $2.5 \mathrm{~m}$. The tracer rhodamine B was added to the spray to be quantified by fluorimetry. Drift prediction models adjusted by exponential functions were obtained considering the $90^{\text {th }}$ percentile for $\mathrm{XR}, \mathrm{TT}, \mathrm{AIXR}$ and TTI nozzles. It is suggested to use the estimated drift models from this study for each nozzle type in drift prediction evaluations on bean crops under brazilian weather conditions.
\end{abstract}

Index terms: Droplet size; spray nozzle; exponential regression; application technology.

\section{RESUMO}

Uma das formas de se evitar a ocorrência de deriva durante as aplicações de produtos fitossanitários é conhecer o comportamento das gotas, antes mesmo de se realizar a pulverização. $O$ trabalho objetivou estabelecer curvas de deriva para as culturas do feijão e nas condições climáticas brasileiras, em função da aplicação com diferentes pontas de pulverização, além de compará-las com os “Modelos Alemão e Holandês" de estimativa de deriva. O experimento foi conduzido no município de Uberlândia, MG/Brasil, em delineamento de blocos casualizados, num esquema de parcela subdividida no espaço 4 × 20, com 10 repetições. Foi mensurada a deriva depositada proveniente da pulverização terrestre, empregando uma taxa de aplicação de $150 \mathrm{~L}$ ha-1 por quatro tipos de pontas (jato plano simples e com indução de ar - XR 11002 (gotas finas) e AIXR 11002 (gotas grossas); jato plano defletor simples e com indução de ar - TT 11002 (gotas médias) e TTI 11002 (gotas extremamente grossas), em 20 pontos amostrais diferentes (correspondentes à 20 distâncias, no sentido de deslocamento do vento, paralelas à linha de cultivo fora da área-alvo, espaçadas em 2,5 m). Para a avaliação dos depósitos em alvos de papel filtro junto ao solo, adicionou-se ao tanque do pulverizador montado de barras um marcador composto do corante Rodamina B para ser detectado por fluorimetria. Obteve-se quatro modelos de previsão de deriva para a cultura do feijão (pontas XR, TT, AIXR e TTI), análogos ao "Modelo Holandês", com tendência exponencial de quatro parâmetros, considerando o Percentil 90 (ajustes acima de 99\%). Em avaliações de estimativa de deriva na cultura do feijão cultivado em condições climáticas brasileiras, sugere-se a utilização dos modelos de previsão de deriva gerados neste trabalho, para cada tipo de ponta de pulverização.

Termos para indexação: Tamanho de gotas; pontas de pulverização; regressão exponencial; tecnologia de aplicação.

\section{INTRODUCTION}

Brazil is the world's largest producer of beans (Phaseolus vulgaris L.), a typical grain that is widely consumed in brazilian cuisine (Mapa, 2015). The crop productivity varies from $411 \mathrm{~kg} \cdot \mathrm{ha}^{-1}$ (Northeast region) to $1,865 \mathrm{~kg} \cdot \mathrm{ha}^{-1}$ (Midwest), with an approximate production cost of $\mathrm{R} \$ 2,800.00$ and $\mathrm{R} \$ 3,800.00$ for rainfed and irrigated beans, respectively. Of this total cost, a margin of between 20 and $25 \%$ represents spending on the acquisition and application of pesticides (Conab, 2015).
Phytosanitary treatments, besides being a considerable share of production cost, are also one of the primary stages of the production process in any cultivation. However, the use of these products can be harmful to the ecosystem on which they are sprayed, either by direct contact with these products during handling or application in the field, or by indirect contact due to the presence of the active molecule of these products in the air, water, soil, or even as a chemical residue in food.

One of the most common problems during their application is related to the pesticide drift (Vercruysse; 
Steurbaut, 2002; Tsai, 2005; De Schampheleire; Spanoghe; Sonckc, 2007). Calculations show that almost $10 \%$ of what is applied in annual crops is lost to surrounding areas, contaminating groundwater and surface water, soil, and air (Jong; Snoo; Zande, 2008), and can reach up to $80 \%$ loss (Maski; Durairaj, 2010). However, there is still insufficient research to prove and quantify the actual value of these losses, as well as the horizontal distance that a droplet can travel under several operating conditions.

Several studies were performed around the world in order to determine the horizontal distance where the sprayed droplets can reach, especially in European Union countries (Yarpuz-Bozdogan; Bozdogan, 2009; Gil et al., 2014; Kasiotis et al., 2014). Usually, the results of those researches are generally presented by exponential or potential functions which express the deposit amount (percentage of pesticide applied per area) depending on the distance between the application area and non-target area (Rautmann; Streloke; Winkler, 2001).

Ganzelmeier et al. (1995) developed the first drift models, known as "German Drift Model," for crops grown in Germany. For each group (cereal, vine, hop, and fruit), there is a curve (power regression) with specific drift coefficients that is used in many regions of the world for studies involving the risk of contamination by drift. Other designs were subsequently developed by Holterman and van de Zande (2003). Known as the "Dutch model," or "IMAG," it proposes drift estimates through exponential and potential regressions for six groups: bare soil (fallow area), potato crops, beets, fruit (fresh and adult), and cereals.

However, both models were established under european weather conditions (temperate climate " $C$ "), which are considerably different from brazilian conditions (tropical climate "A") (Peel; Finlayson; McMahon, 2007). In addition, neither of these models propose drift estimates specifically for beans.

The German and Dutch models feature drift curves without droplet size distinction, although some studies have found that droplet size directly influences their behavior. In an evaluation of the effects of drift due to different nozzles types, working pressures, and boom heights, it was found that venture nozzle type have the greatest potential for reducing drift, followed by preorifices and flat-fan standard nozzles (Nuyttens et al., 2007). In most cases, the drift is directly related to the size of the spray droplets, particularly the amount of fine droplets (Arvidsson; Bergtrom; Kreuger, 2011; Nuyttens et al., 2010, 2011), in both aerial and ground spraying (van de Zande et al., 2010).
Thus, this study aimed to establish drift curves from applications on bean crop in brazilian climatic conditions using different spray nozzles, and compare them with the "German" and "Dutch" drift prediction models.

\section{MATERIALS AND METHODS}

The experiment was conducted at the Capim Branco Experimental Station, belonging to the Federal University of Uberlândia, located in the city of Uberlandia, Minas Gerais, Brazil. The area is located at an altitude of $837 \mathrm{~m}, 18^{\circ} 53^{\prime} 287^{\prime \prime} \mathrm{S}$ latitude and $48^{\circ} 20^{\prime} 514^{\prime \prime} \mathrm{W}$ longitude, with flat topography and Aw climate (tropical humid with dry winters). The laboratory evaluations were performed at the Agricultural Mechanization Laboratory (Laboratório de Mecanização Agrícola - LAMEC), part of the Institute of Agricultural Sciences (Instituto de Ciências Agrárias - ICIAG/UFU), also located in Uberlândia.

For the drift evaluation assay, a commom bean plot was planted in a field with a central pivot irrigation system on July 21, 2013. The area was harrowed seven days before sowing and phytosanitary treatments were performed according to the crop needs. Evaluations took place between 18 until 24 September, 2014, when the crop was at the R8 (filling pods) and early R9 (maturation) stages, according to the classification proposed by Fernandez, Gepts and Lopes (1986). At the moment of application, bean plants were $0.45 \mathrm{~m}$ tall, with a leaf area index (LAI) of 1.9:1 (Watson, 1947).

A completely randomized design in a $4 \times 20$ split plot arrangement with 10 replicates was set up, corresponding to four nozzles types: flat-fan standard XR 11002 (fine droplets); flat fan deflector standard - TT 11002 (medium droplets); flat fan venture - AIXR 11002 (coarse droplets) and flat fan deflector venture - TTI 11002 (extremely coarse droplets). And 20 downwind distances from the treated area parallel to the crop line, spaced by $2.5 \mathrm{~m}$ (Figure 1). The droplet size was according to the manufacturer Teejet ${ }^{\circledR}$, at $300 \mathrm{kPa}$ (3 bar) pressure.

To quantify the deposited drift, horizontal collectors were placed at ground level downwind from the application site, parallel to the cultivation row outside the target area (area with no cultivation) (Figure 1). Filter papers were used as collectors with dimensions of $38 \times 7 \mathrm{~cm}\left(266 \mathrm{~cm}^{2}\right)$ and a weight of $65 \mathrm{~g}$. The collectors were positioned from $2.5 \mathrm{~m}$ up to $50 \mathrm{~m}$ downwind from the treated area, separated by $2.5 \mathrm{~m}$; at each distance, four collectors were lined up side by side, separated by $1.5 \mathrm{~m}$ (the total area of the collectors was 1,064 $\mathrm{cm}^{2}$ ). The collectors were attached on polyethylene holders to prevent contamination by soil particles. 


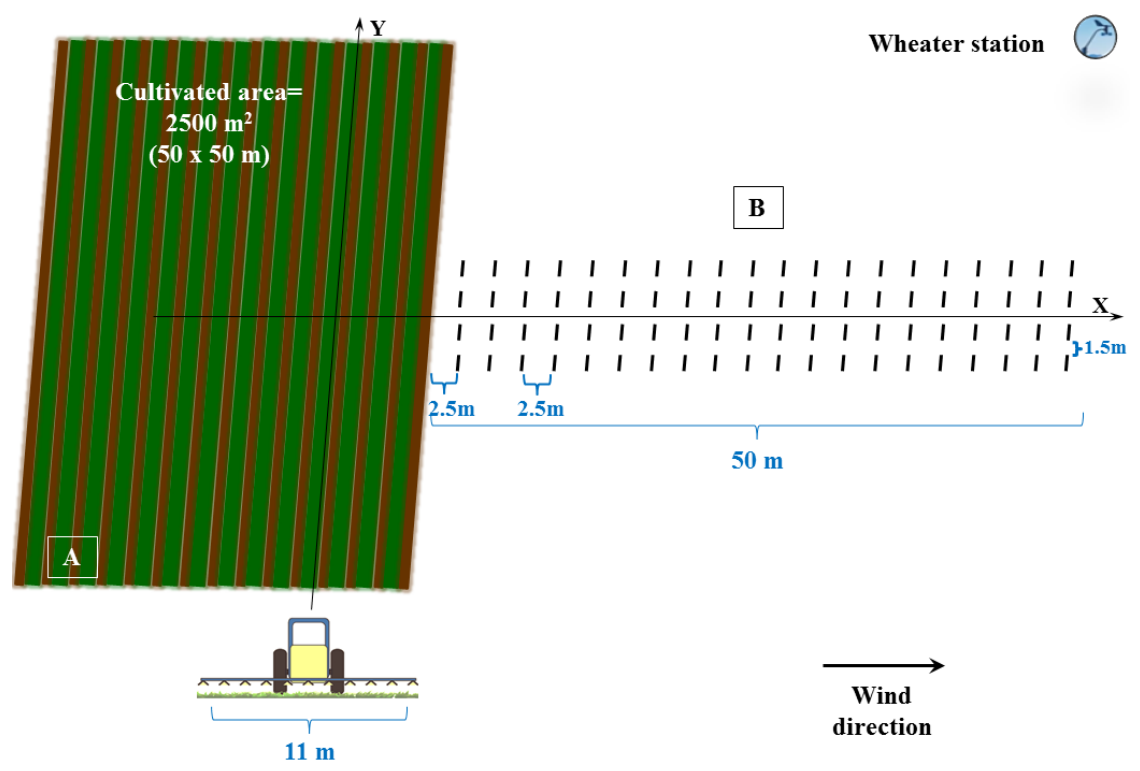

Figure 1: Description of the location where the field test was performed and the placement of the collectors for drift evaluation.

Where:

$\mathrm{Y}=$ spray line

$\mathrm{X}=$ horizontal axis perpendicular to the spray line

$\mathrm{A}=$ treated area

$\mathrm{B}=$ drift zone

Application was made at $22 \mathrm{~m}$ width (equivalent to two passes of the sprayer) by $50 \mathrm{~m}$ length, performed perpendicularly to the prevailing wind direction.

Applications were conducted using the mounted hydraulic sprayer FM Coupling, Model JB 80/400, 400 L tank capacity, $12 \mathrm{~m}$ boom width and 24 nozzles spaced $0.5 \mathrm{~m}$ apart. The sprayer was coupled to a $4 \times 2$ Ursus tractor with $85 \mathrm{hp}(62.5 \mathrm{~kW})$. The boom was positioned at $0.5 \mathrm{~m}$ above the crop. To achieve $150 \mathrm{~L} \mathrm{ha}^{-1}$ carrier volume, $300 \mathrm{kPa}$ pressure ( $3 \mathrm{bar}$ ) and $1.8 \mathrm{~m} \mathrm{~s}^{-1}$ speed travel $\left(6.5 \mathrm{~km} \mathrm{~h}^{-1}\right)$ were used.

Weather data were monitored through a Davis Vantage PRO2 ${ }^{\mathrm{TM}}$ weather station, located $100 \mathrm{~m}$ from the application area and $2.0 \mathrm{~m}$ above the ground, connected in real time to a digital console that provided temperature, humidity, wind speed and wind direction data at the time of application. The ISO 22866 standard (ISO, 2005) have indicate that the temperature during application must be between 5 and $35^{\circ} \mathrm{C}$, the minimum wind speed must be $1.0 \mathrm{~m} \mathrm{~s}^{-1}$, and the wind direction must be within a $90^{\circ} \pm$ $30^{\circ}$ limit relative to the spray line.

Rhodamine $\mathrm{B}$ was used as tracer at $100 \mathrm{mg} \mathrm{L}^{-1}$ to be detected in laboratory by fluorimetry, according to the methodology proposed by Scramin et al. (2002). Quantification was performed by a fluorimeter (Thermo Scientific FM 109515) with 540 ๆm and 585 ๆm excitation and emission filters, respectively. The sensitivity measured by the apparatus was $1 \eta \mathrm{g} \mathrm{mL}^{-1}$. According to Alves, Cunha and Palladini (2014), among the low-cost markers available in Brazil, rhodamine B was the best option when filter paper is used as the application target. This marker has little influence on the physicochemical characteristics of the spray and is stable under sunlight, presenting low degradation during the investigative period, as long as the exposure does not exceed 60 minutes.

After application, the four collectors from each line were collected, stored in labelled plastic bags and packaged in a cooler until arrival at the laboratory, where they were kept under refrigeration at $5{ }^{\circ} \mathrm{C}$ and absence of light until the processing time, in order to prevent photodegradation. The fluorimeter was calibrated using a standard solution at concentration of $200 \mathrm{\eta g} \mathrm{mL}^{-1}$, prepared with distilled water.

As extraction procedure of the tracer from each sample, $100 \mathrm{~mL}$ of an aqueous solution containing $0.2 \%$ Tween 80 (Polysorbate 80) was added into each plastic bag, and then the samples were stirred for 15 minutes at $120 \mathrm{rpm}$ on an orbital shaker table (Tecnal TE 240/1). After 10 minutes at rest, the solution was transferred to plastic cups to proceed the reading in the fluorometer. All extraction steps were also performed protecting the tracer against photodegradation. 
From the fluorometer reading, the calibration readings, the collector surface area $\left(\mathrm{cm}^{2}\right)$, the real concentration of the marker in the spray solution and the application rate, the amount of sprayed deposit per unit area was calculated. The luminance data extracted from the papers were converted to the percentages of drift at each distance, relating the deposit to the amount applied to the field (ISO, 2005) as detailed in Equations 1 and 2.

$$
\begin{aligned}
& \beta_{\text {dep }}=\frac{\left(\rho_{\text {sample }}-\rho_{\text {blank }}\right) \times F_{\text {cal }} \times V_{\text {dil }}}{\rho_{\text {spray }} \times A_{\text {col }}} \\
& \beta_{\text {dep } \%}=\frac{\beta_{\text {dep }} \times 10000 \mathrm{~m}^{2} / \mathrm{ha}}{\beta_{V}}
\end{aligned}
$$

Where:

$\beta_{\text {dep }}$ : spray drift deposit $\left(\mu \mathrm{L} \mathrm{cm}^{-2}\right)$;

$\beta_{\text {dep } \%}$ : spray drift percentage $(\%)$;

$\beta \mathrm{V}$ : spray volume $\left(\mathrm{L} \mathrm{ha}^{-1}\right)$;

$\rho_{\text {sample }}$ fluorimeter reading of the sample $\left(\eta \mathrm{gL}^{-1}\right)$;

$\rho_{\text {blank }}$ : fluorimeter reading of the blanks (collector + distilled water) ( $\left.\eta \mathrm{mL}^{-1}\right)$;

$F_{\text {cal }}:$ calibration fator - relationship between the fluorimeter reading and tracer concentration (Adimensional);

$V_{\text {dil }}$ : volume of dilution liquid (water) used to extract the tracer from collector $(\mathrm{L})$;

$\mathrm{P}_{\text {spray }}$ : spray concentration, or amount of tracer in the spray liquid sampled, in the spray tank $\left(\mathrm{g} \mathrm{L}^{-1}\right)$;

$A_{\text {col }}:$ projected area of the collector for catching the spray drift $\left(\mathrm{cm}^{2}\right)$.

Firstly, the data were subjected to the assumption tests: normality of the residuals and homogeneity of variance by Kolmogorov-Smirnov and Levene tests, respectively, at 0.05 significance level using SPSS 17.0 software (SPSS, 2012).

In cases where one or more assumptions were not reached, the data were transformed by arcsine $\sqrt{x / 100}$ for better fit. The drift percentage data were subjected to Snedecor's $F$-test at 0.05 significance. Means between nozzles were compared by Tukey's multiple comparison test, whereas means between distance were subjected to regression analysis, both at 0.05 significance, using Sisvar 5.3 statistical software (Ferreira, 2011).

The regression models were tested using Sigma Plot 11.0 software (Systat Software Inc., 2014) regarding significance (0.05) and goodness of fit (coefficient of determination $-\mathrm{R}^{2}$ ). When significant, the equations of the four nozzles were compared using the confidence intervals (95\% reliability at the lower and upper limits) generated using the same software.

An adequacy study of the coefficients of the "German" (Ganzelmeier et al., 1995; Rautmann; Streloke; Winkler, 2001) and "Dutch" drift models (Holterman; van de Zande, 2003) to the field data was also performed. For comparison with these two models, the observed means (original) of each nozzle were initially converted to the $90^{\text {th }}$ percentiles (calculated by Microsoft Excel 2010), and the estimated curves were compared to the curves of the German and Dutch Drift models by means of the confidence intervals ( $95 \%$ reliability in the lower and upper limits) generated using Sigma Plot 11.0 software. Transformation to the $90^{\text {th }}$ percentile was performed because this measure is the same used in the two comparative models. So it was necessary to do the transformation to permit comparison.

It is important to note that neither of the two models has specific drift curves to commom bean crop. Therefore, comparisons with the German and Dutch model coefficients were used for drift equations from two categories: "Field Crops" and "Cereals", respectively (De Schampheleire; Spanoghe; Sonckc, 2007), as detailed in Equations 3 and 4.

\section{- German Drift Model}

$\%$ drift $=A z^{-B}$

- Dutch Drift Model or IMAG

$\%$ drift $=A_{0} e^{-z \cdot A_{1}}+B_{0} e^{-z \cdot B_{1}}$

Where:

\%drift: percentage of drift (\%);

$\mathrm{z}$ : downwind distance from treated area $(\mathrm{m})$;

A: 2.7593 (coefficient of the German drift equation for the category Field Crops);

B: - 0.9778 (coefficient of the German drift equation for the category Field Crops);

$A_{0}: 39$ (coefficient of the Dutch drift equation for the category Cereals);

$\mathrm{A}_{1}: 0.90$ (coefficient of the Dutch drift equation for the category Cereals);

$\mathrm{B}_{0}: 2.28$ (coefficient of the Dutch drift equation for the category Cereals);

$\mathrm{B}_{1}: 0.147$ (coefficient of the Dutch drift equation for the category Cereals); 


\section{RESULTS AND DISCUSSION}

All weather conditions during the applications were in accordance to the ISO 22866 standard (ISO, 2005) (Table 1).

Conditions of temperature, humidity and wind speed presented similar mean values for all nozzle types. These similarities are important because among the various factors that affect drift behaviour during pesticide applications, the environmental and meteorological conditions (temperature, humidity and wind speed) are the most important. Baetens et al., 2007; Arvidsson; Bergtrom; Kreuger, 2011; Hilz; Vermeer, 2013; Gil et al., 2014).

Regarding the percentage of drift deposited up to $50 \mathrm{~m}$ away from the point of application, the relationship between the spray nozzle type and distance factors was significant, indicating that the nozzle nozzle (and hence droplet size) directly affected the drift. The flat-fan standard nozzle (XR 11002/fine droplets) had the highest percentage of drift relative to the others, up to $12.5 \mathrm{~m}$ from the treated area. At $15 \mathrm{~m}$, the drift of this nozzle was higher only in relation to the air induction nozzles (AIXR 11002/coarse droplets and TTI 11002/extremely coarse droplets); it did not differ from the flat-fan deflector standard spray nozzle (TT 11002/medium droplets). Over $17.5 \mathrm{~m}$ the drift from all nozzles was similar, with values under 1\% (Table 2 and Figure 2).
The exponential model with four parameters (Equation 4), similar to the models proposed by Holterman and van de Zande (2003), showed to have the best fit $\left(\mathrm{R}^{2}\right)$ to the drift data in comparison with other models (potential and exponential with one, two and three parameters). Despite presenting $\mathrm{R}^{2}$ values above $99 \%$ for the percentage of drift for all the nozzles, there was a model adjustment only for non-air induction XR and TT nozzles (Table 3 and Figure 2).

Figure 2 represents the percentage of drift deposited per spray nozzle as a function of distance. The point at which the lower limit of the XR nozzle crosses the upper limit of the TT nozzle indicates that the curves are similar over $12.5 \mathrm{~m}$ from the target area. The drift decreases exponentially as the spray moves away from the target area, with the highest percentage of drift when using XR nozzle, which produced fine droplets.

Kasiotis et al. (2014) evaluated the effect of drift reduction during an herbicide application simulation in a fallow field with the use of low-drift nozzles (AIXR 11002-coarse droplets, and AIXR 11004-extremely coarse droplets), in comparison with the use of conventional flat-fan nozzles (local manufacturing-fine to medium droplets), it was found that the highest percentage of drift was obtained when conventional flat-fan spray nozzles were used. The AIXR 11002 nozzle showed the lowest

Table 1: Mean values of weather conditions collected during the applications on commom bean crop using four different spray nozzles (droplet size).

\begin{tabular}{|c|c|c|c|c|}
\hline \multirow{2}{*}{ Weather Condition } & XR Nozzle & TT Nozzle & AIXR Nozzle & TTI Nozzle \\
\hline & \multicolumn{4}{|c|}{ Means ${ }^{1}$ (Standard Deviation) } \\
\hline Temperature $\left({ }^{\circ} \mathrm{C}\right)$ & $26.8 \pm 3.1$ & $26.8 \pm 3.4$ & $26.9 \pm 3.3$ & $26.9 \pm 3.3$ \\
\hline Relative humidity (\%) & $56.6 \pm 13.5$ & $56.8 \pm 14.3$ & $56.4 \pm 13.7$ & $56.3 \pm 12.8$ \\
\hline Wind speed $\left(\mathrm{m} \mathrm{s}^{-1}\right)$ & $3.0 \pm 1.0$ & $3.3 \pm 1.4$ & $3.5 \pm 1.2$ & $3.2 \pm 1.4$ \\
\hline Ideal wind direction & $\mathrm{E}\left(\mathrm{NNE}^{2}\right)$ & $\mathrm{E}\left(\mathrm{NNE}^{2}\right)$ & $\mathrm{E}\left(\mathrm{NNE}^{2}\right)$ & $\mathrm{E}\left(\mathrm{NNE}^{2}\right)$ \\
\hline Acceptable wind directions & $\begin{array}{l}\text { ENE/ E /ESE } \\
\left(\mathrm{N} / \mathrm{NNE} / \mathrm{NE}^{2}\right)\end{array}$ & $\begin{array}{l}\text { ENE/ E /ESE } \\
\left(\mathrm{N} / \mathrm{NNE} / \mathrm{NE}^{2}\right)\end{array}$ & $\begin{array}{l}\text { ENE/ E /ESE } \\
\text { (N/NNE /NE2) }\end{array}$ & $\begin{array}{l}\text { ENE/ E / ESE } \\
\left(\mathrm{N} / \mathrm{NNE} / \mathrm{NE}^{2}\right)\end{array}$ \\
\hline Predominant wind direction & ENE $\left(\mathrm{NE}^{2}\right)$ & $\mathrm{E}\left(\mathrm{ENE}^{2}\right)$ & ENE $\left(\mathrm{NE}^{2}\right)$ & ENE $\left(\mathrm{NE}^{2}\right)$ \\
\hline $\begin{array}{l}\text { Wind direction }\left({ }^{\circ}\right) \text { in relation to } \\
\text { the ideal direction }\left(90^{\circ}\right)\end{array}$ & $24.8 \pm 12.8$ & $13.5 \pm 11.6$ & $22.5 \pm 15.0$ & $20.3 \pm 16.6$ \\
\hline
\end{tabular}

${ }^{1}$ Values derived from the mean of 10 replicates of each nozzle. For each replicate, there were approximately three minutes of application; in each minute, an average value of all of the conditions was obtained according to the frequency of the apparatus, $1 \mathrm{~Hz}$. ${ }^{2}$ The days that the wind direction change, the collectors and the application direction have changed position, to meet the requarements of the ISO 22866 standard. 
percentage of drift, even with droplets smaller than those produced by the AIXR 11004 nozzle, a difference attributed by the authors to the wind speed variation during application: 1.0 to $2.2 \mathrm{~m} \cdot \mathrm{s}^{-1}$ for the 11002 nozzle, as opposed to 1.1 to $4.2 \mathrm{~m} \cdot \mathrm{s}^{-1}$ for the 11004 nozzle. This result shows that the wind speed is one of the factors that most influences the movement of the droplets to non-target areas (Arvidsson; Bergtrom; Kreuger, 2011).

Also from the study of Kasiotis et al. (2014), it is observed that AIXR 11002, AIXR 11004, and flat-fan nozzles considerably reduced drift ( $0.1 \%$ drift $)$ at a distance of 2,4 , and $10 \mathrm{~m}$ from the application target area, respectively.

Table 2: Percentages of drift deposited from $2.5 \mathrm{~m}$ to $50 \mathrm{~m}$ from the treated area, resulting from applications through four nozzles types (droplet sizes).

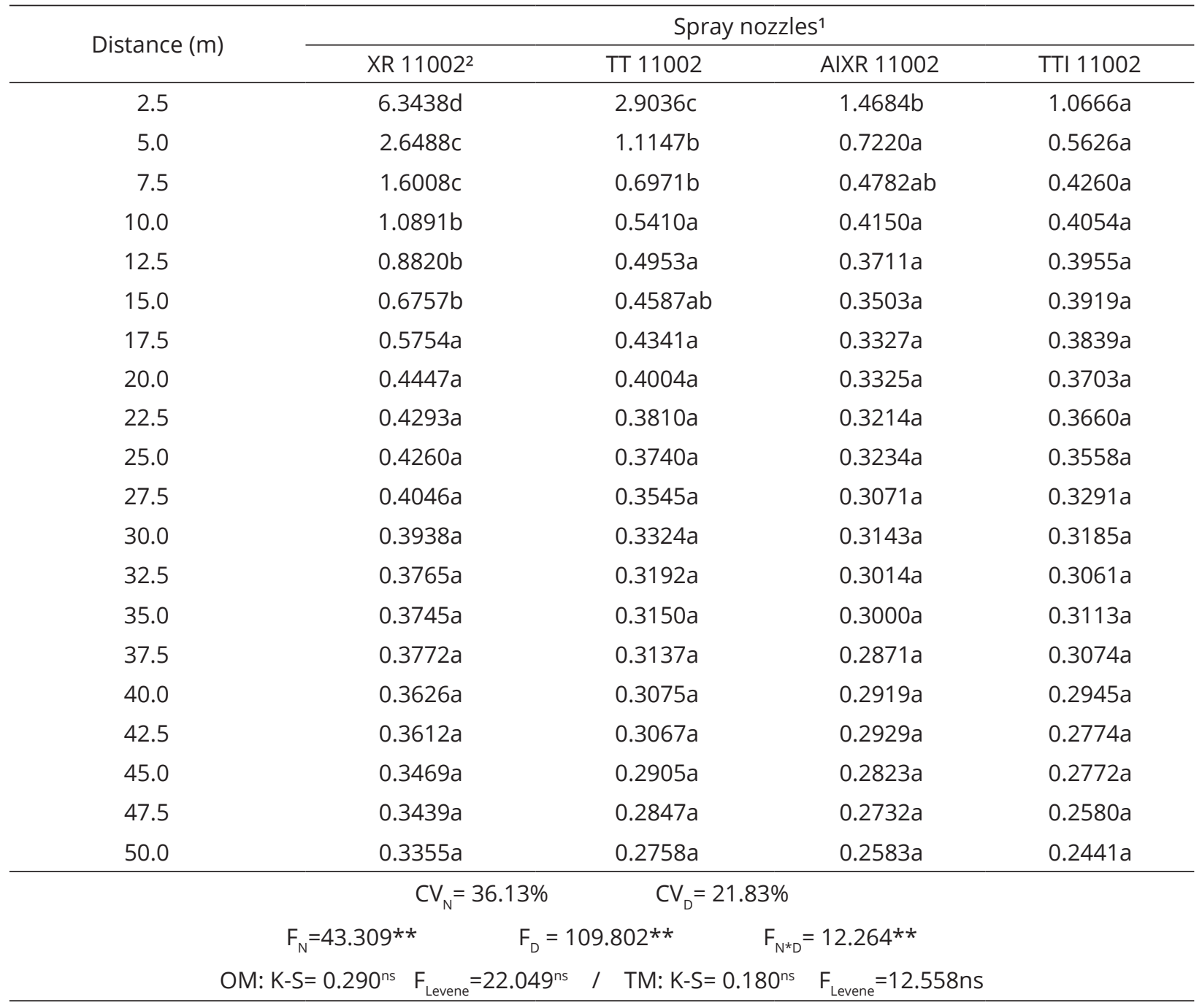

${ }^{1}$ XR: Flat-fan standard nozzle; TT: Flat-fan deflector standard nozzle; AIXR: Flat-fan standard nozzle with air induction; TTI: Flat-fan deflector standard nozzle with air induction. ${ }^{2}$ Means followed by different letters in the row differ by Tukey's test at 0.05 significance. $\mathrm{CV}_{\mathrm{SN}} ; \mathrm{CV}_{\mathrm{D}}$ : Coefficients of variation for the variables Spray Nozzles and Distance, respectively. $\mathrm{F}_{\mathrm{SN}} ; \mathrm{F}_{\mathrm{D}} ; \mathrm{F}_{\mathrm{PxD}}$ : Values of $\mathrm{F}$ calculated for the variables Spray Nozzles and Distance and for the interaction between the Nozzle and Distance, respectively; K-S; $\mathrm{F}_{\text {Levene }}$ : Values of F for the Kolmogorov-Smirnov and Levene's tests, respectively, calculated for the original means (OM) and transformed means (TM) by arcsine $\sqrt{x / 100}$. Data from all nozzles were transformed. $* *$ Significant at $0.01 ;{ }^{\text {ns }}$ non-significant. 


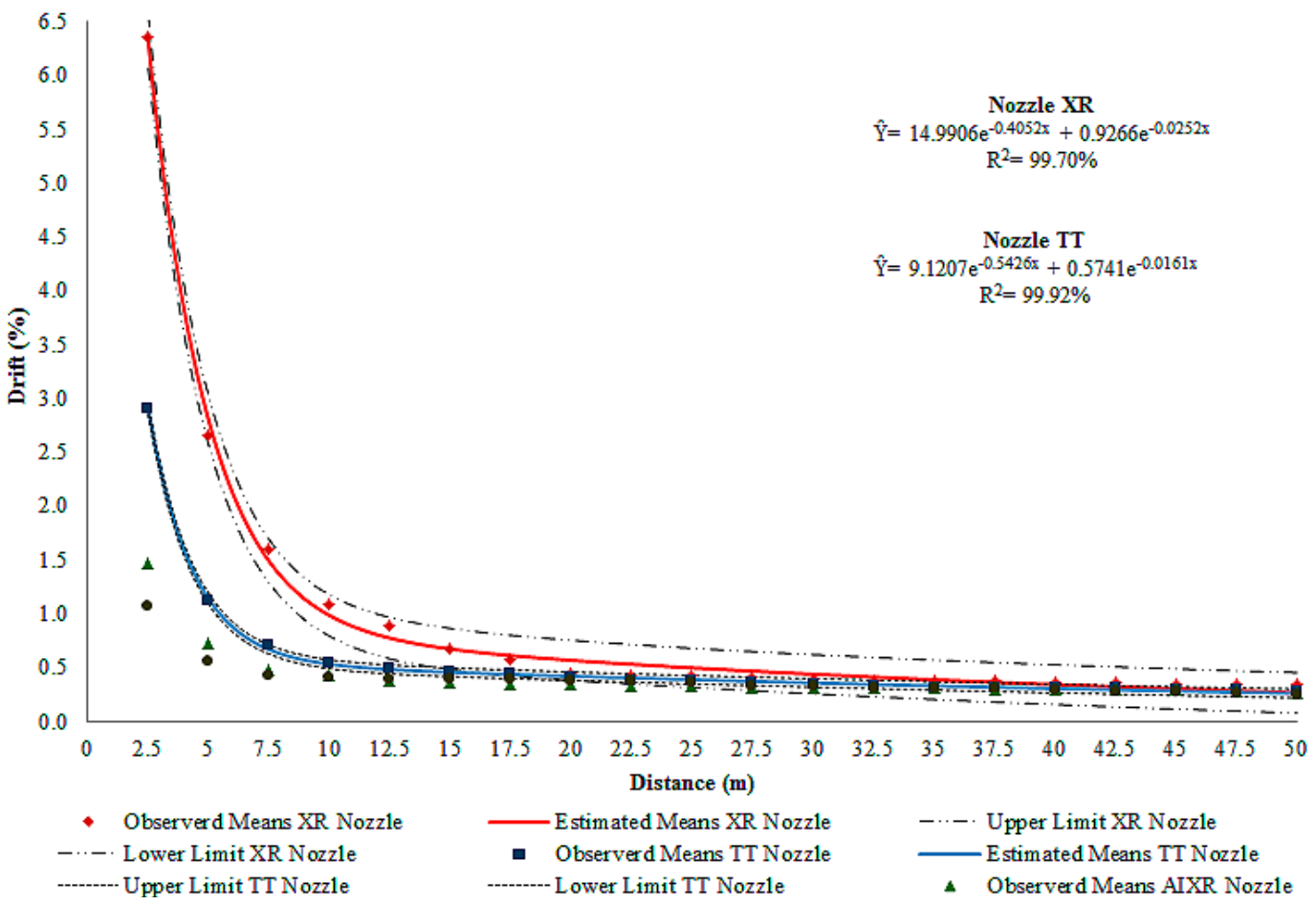

Figure 2: Drift curves from applications on commom bean crop through four nozzles types (droplet size), with their respective confidence interval curves ( $95 \%$ reliability in the lower and upper limits).

Table 3: Summary of the analysis of variance of observed drift data for assessing the distance within each nozzle (droplet size).

\begin{tabular}{crrrrrc}
\hline Nozzle & dof & Mean square & \multicolumn{1}{c}{$\mathrm{Fc}^{1}$} & \multicolumn{1}{c}{$\mathrm{Ft}^{2}$} & Equation & $\mathrm{R}^{2}$ \\
\hline XR & 3 & 12.2422 & 44.2594 & $2.60^{*}$ & $\hat{\mathrm{Y}}=14.9906 \mathrm{e}^{-0.4052 x}+0.9266 \mathrm{e}^{-0.0252 x}$ & 99.70 \\
TT & 3 & 2.1873 & 7.9078 & $2.60^{*}$ & $\hat{\mathrm{Y}}=9.1207 \mathrm{e}^{-0.5426 x}+0.5741 \mathrm{e}^{-0.0161 x}$ & 99.92 \\
AIXR & 3 & 0.4655 & 1.6829 & $2.60^{\text {ns }}$ & - & - \\
TTI & 3 & 0.1969 & 0.7119 & $2.60^{\text {ns }}$ & - & - \\
Error & 684 & 0.2766 & & & & - \\
\hline
\end{tabular}

*, ns Significant and non-significant models, respectively, according to the F-test at 0.05 significance. ${ }^{1} \mathrm{~F}_{\mathrm{c}}$-calculated; ${ }^{2} \mathrm{~F}_{\mathrm{c}}$-tabulated.

Gil et al. (2014) concluded that AIXR and TTI air induction nozzles generally resulted in smaller drift potential when compared with nozzles without air induction (XR and TT). When drift reduction potential was calculated and compared with standard treatment (XR 11003), the authors found that TTI nozzle had the highest potential to reduce drift $(88.5 \%)$, followed by TT nozzle (64.1\% ) and the AIXR nozzle (58.6\%).

In general, fine droplets result in higher percentage of drift when closer to the target areas. However, in a study carried out in Adana, Turkey, with the aim of assessing the drift of Malathion insecticide, the finest droplets generated through hollow cone nozzle HC D445 produced the lowest percentage of $\operatorname{drift}(7.141 \%) 1 \mathrm{~m}$ away from the target area, whereas medium droplets produced $8.242 \%$ (flat-fan standard nozzles F 11006) and coarse droplets produced $9.95 \%$ (low-drift flat-fan nozzle LD 11003). At $5 \mathrm{~m}$, the drift percentages were: 0.742 , 0.685 , and $0.663 \%$ for fine, medium, and coarse droplets, respectively (Yarpuz-Bozdogan; Bozdogan, 2009). 
Despite not very clear, the authors explain the results based on the theory proposed by Matthews and Hamey (2003), in which fine droplets drift greater distances depending on their own behavior and the weather; while coarse droplets trend to be deposited closer to the treated fields.

The difference in the deposition behavior of droplets between the results from Yarpuz-Bozdogan and Bozdogan (2009) and the present study is probably due to the difference in data collection points: The authors used a total of 5 sampling points between 1 and $5 \mathrm{~m}$ away from the target area, while this study used 20 sampling points between 2.5 and $50 \mathrm{~m}$ away.

For the original drift percentage data converted to the $90^{\text {th }}$ percentile, there are models of adjustment for the four nozzles, again with $\mathrm{R}^{2}$ above $99 \%$, indicating a good fit for all curves (Table 4 and Figure 3). Each of these curves was compared to the German and Dutch models through confidence intervals (Figures 4, 5, 6 and 7).

Table 4: Summary of the ANOVA for the observed drift data converted into 90th percentiles (P90) for understanding the distance between each nozzle (droplet size) evaluated for the dry bean crop.

\begin{tabular}{crrrrcc}
\hline Nozzle & dof & QM & Fc & Ft & Equation & $R^{2}$ \\
\hline XR & 3 & 33.9493 & 122.7374 & $2.60^{*}$ & $\hat{Y}=30.7647 \mathrm{e}^{-0.4949 x}+1.8278 \mathrm{e}^{-0.0347 x}$ & 99.66 \\
TT & 3 & 7.3197 & 26.4630 & $2.60^{*}$ & $\hat{Y}=20.2565 \mathrm{e}^{-0.5923 x}+0.6914 \mathrm{e}^{-0.0077 x}$ & 99.97 \\
AIXR & 3 & 1.4646 & 5.2950 & $2.60^{*}$ & $\hat{Y}=7.5039 \mathrm{e}^{-0.5222 x}+0.5485 \mathrm{e}^{-0.0046 x}$ & 99.84 \\
TTI & 3 & 0.8387 & 3.0322 & $2.60^{*}$ & $\hat{Y}=6.7700 \mathrm{e}^{-0.5943 x}+0.5482 \mathrm{e}^{-0.0047 x}$ & 99.90 \\
Error & 684 & 0.276601 & & & & \\
\hline
\end{tabular}

* Significant models according to the $\mathrm{F}$ test at 0.05 significance.

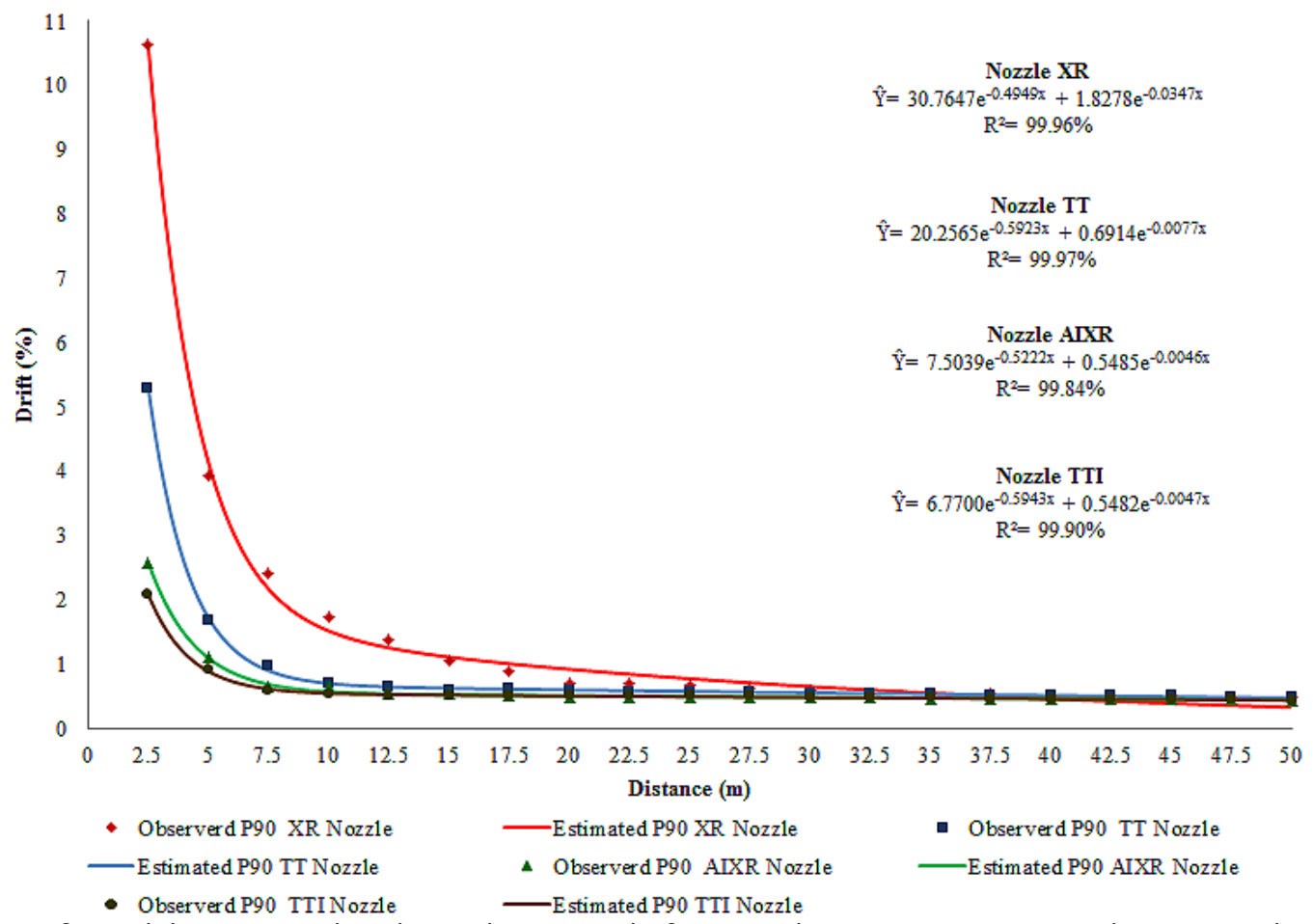

Figure 3: Drift models estimated in the 90th percentile from applications on commom bean crop through four nozzles types (droplet size). 
According to Figures 4, 5, 6 and 7, there is no difference between the estimated models for XR, TT, AIXR, and TTI nozzles and the German and Dutch models, once either the upper or lower limit (lower limits from some curves do not appear due to having negative values) of the German and Dutch models intersect with the estimated limits of the four nozzles at some point on the curve (usually between 2.5 and $5 \mathrm{~m}$ ).

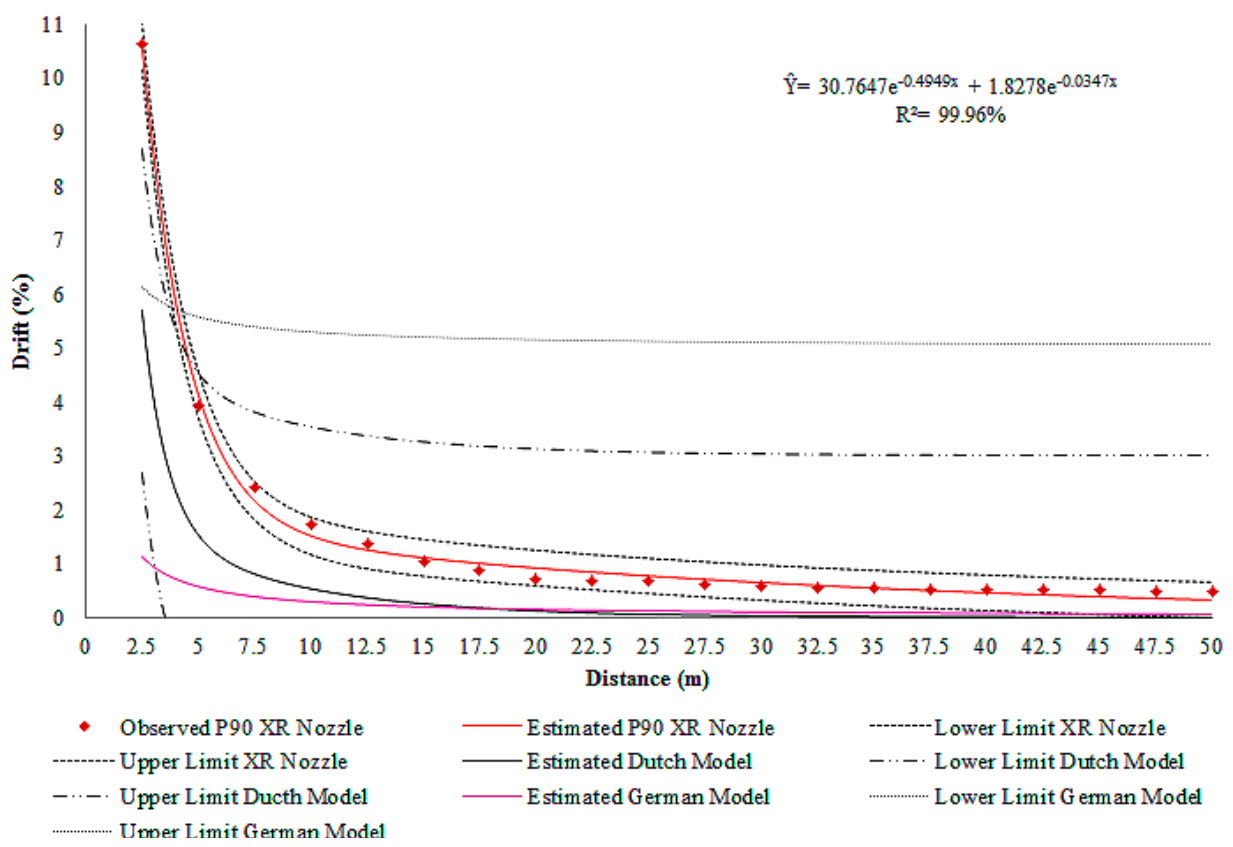

Figure 4: Comparison of the estimated drift model for the flat-fan standard nozzle (XR 11002/fine droplets) and the "German and Dutch models" for drift data converted into $90^{\text {th }}$ percentile.

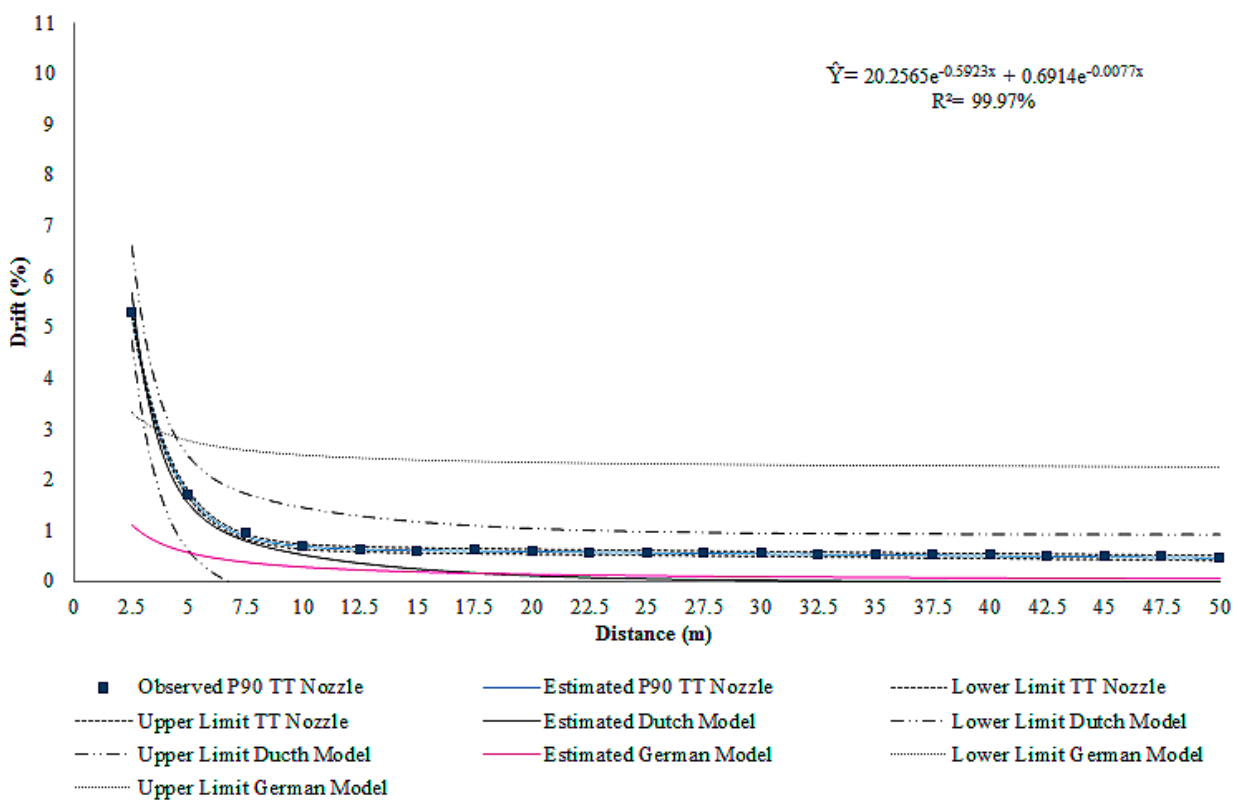

Figure 5: Comparison of the estimated drift model for the flat-fan deflector standard nozzle (TT 11002/medium droplets) and the "German and Dutch models" for drift data converted into the $90^{\text {th }}$ percentile. 
It is noteworthy to highlight that, despite the similarity between the curves, the limits of the German and Dutch models have large amplitudes, and in most cases, completely cover the curve and the estimated limits for the studied nozzles, as occurs with the TT nozzle curve in relation to the Dutch model (Figure 5).

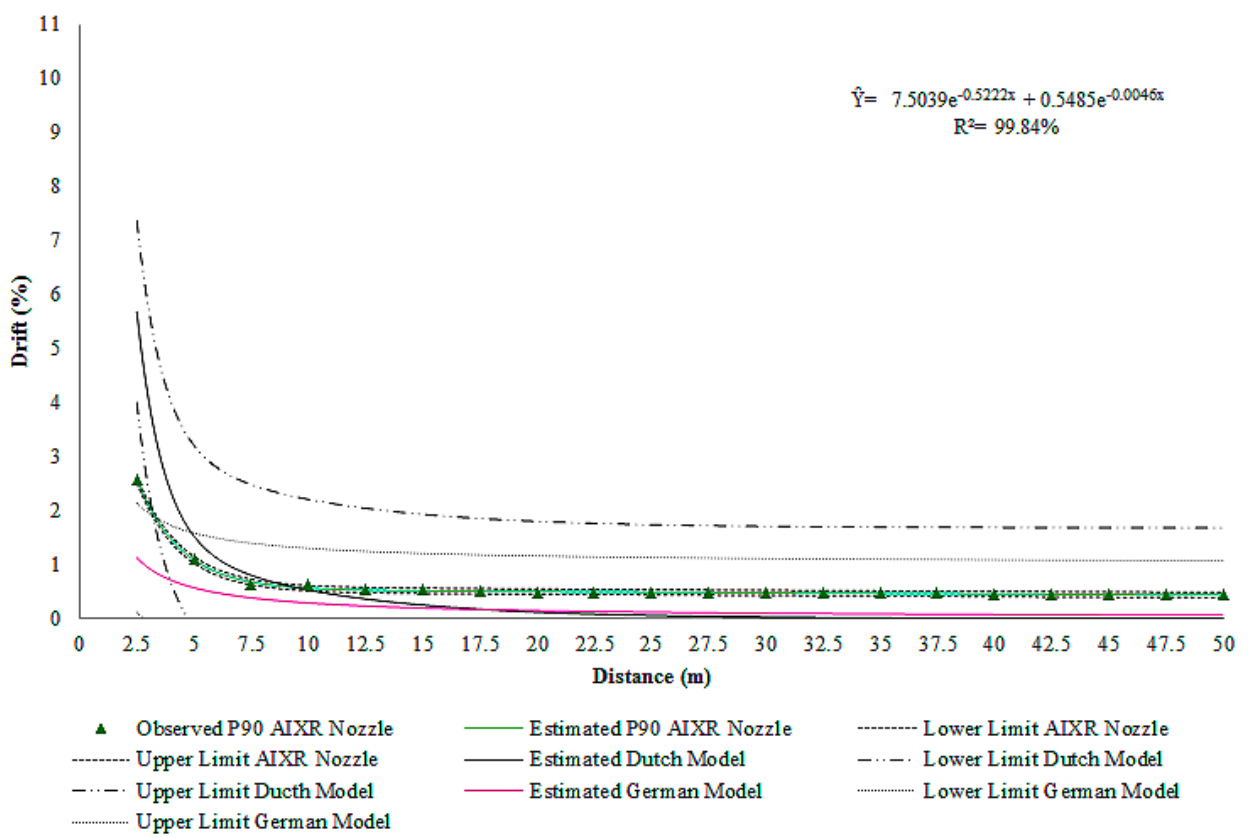

Figure 6: Comparison of the estimated drift model for the flat-fan standard nozzle with air induction (AIXR 11002/ large droplets) and the "German and Dutch models" for drift data converted into the $90^{\text {th }}$ percentile.

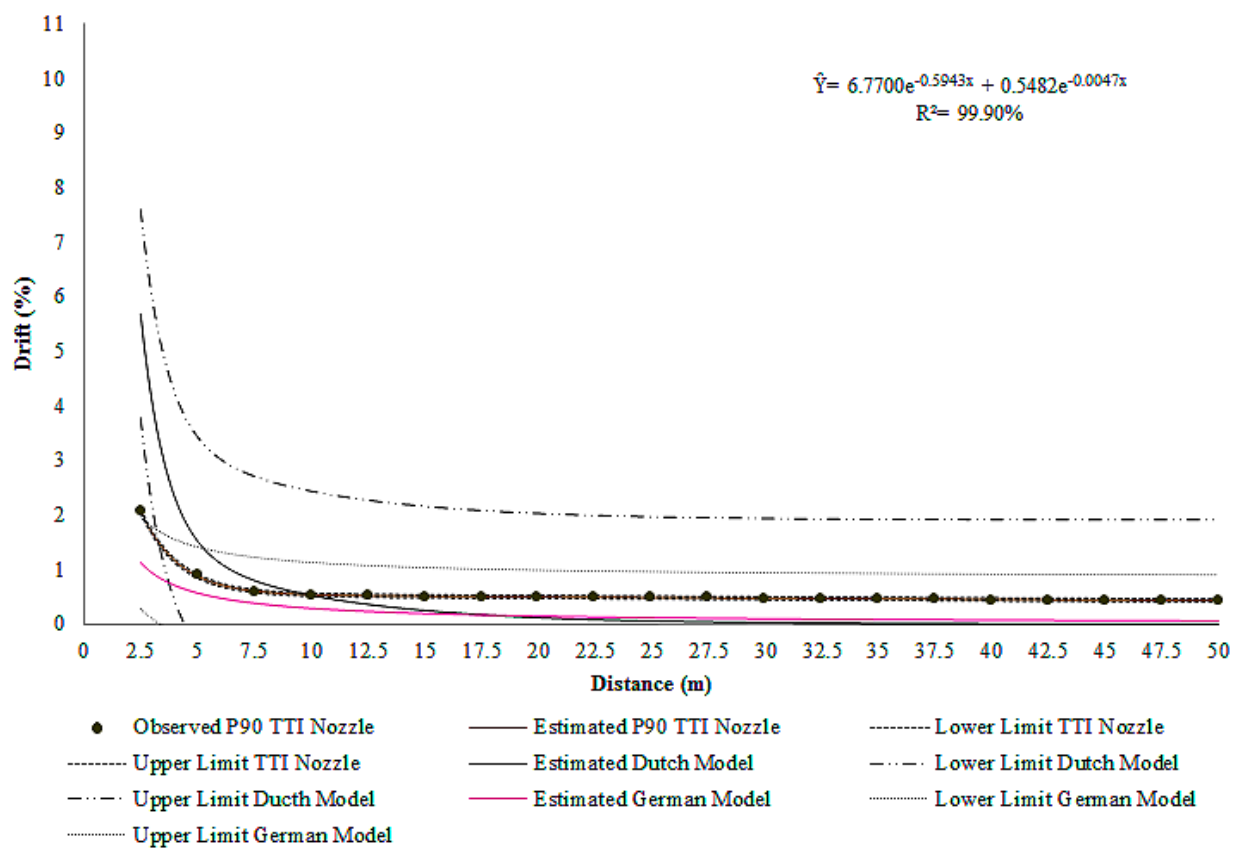

Figure 7: Comparison of the estimated drift model for the flat-fan deflector standard nozzle with air induction (TTI 11002/medium droplets) and the German and Dutch models for drift data converted into the $90^{\text {th }}$ percentile. 
Thus, although the type of equation for the Dutch model is more suited to the data (presented best fit: $\mathrm{R}^{2}$ in relation to the potential equation for the German model), the coefficients of equation $\left(\mathrm{A}_{0}, \mathrm{~A}_{1}, \mathrm{~B}_{0}\right.$, and $\mathrm{B}_{1}$ for the category "Cereals") used for model comparison were not appropriate. If a model has large confidence intervals, it implies that the model is very generic, for example, in this specific case where clear different percentages of drift are statistically similar, which is not a desired feature in a drift prediction model. Thus, it was possible to infer that the Dutch drift model of cereal cropping is not suitable for estimating the drift for bean crop.

This fact can be explained on the basis that the drift percentages of both the "German and the Dutch models", besides being applicable to different cropping systems and different operational and climatic conditions in relation to this experiment, are based on applications with different nozzle types and different droplet sizes. The German model, for example, was initially based on results of 119 drift studies conducted between 1989 and 1992 (Ganzelmeier et al., 1995), and was subsequently applied to over 50 tests for low-scale crops and 72 trials for fruit crops from 1996 to 1999 (Rautmann; Streloke; Winkler, 2001).

The Dutch model was based on several tests that different authors performed between 1992 and 1999, also with different nozzle types, although primarily using flat-fan standard nozzles with medium droplet spectrum (Holterman; van de Zande, 2003).

When observing the behavior of the major curves (i.e., the estimated model for each nozzle, and the German and Dutch models), it was also possible to verify that in all cases, the curves from the German model (Figures 4-7) underestimated the percentage of drift.

The curves from the Dutch model underestimated the drift when compared with the curve of the XR nozzle (fine droplets), overestimated the drift when compared with the curves of the AIXR (coarse droplets) and TTI nozzles (extremely coarse droplets), especially up to 10.0 $\mathrm{m}$, and showed a pattern similar to the estimated curve for the TT nozzle (medium droplets).

Similarity between the curves from TT nozzle and from the Dutch model can be explained by the fact that the tests conducted to estimate the Dutch model for "Cereals" crops (coefficients for estimating the Dutch model adopted in this study) were carried out using a XR 11004 nozzle which produced medium droplets (Holterman; van de Zande, 2003), the same pattern of droplets produced by TT 11002 nozzle. Therefore, it can be inferred that nozzle type is one of the most important factors in the characterization and determination of drift curves, and hence the droplet size.
Yarpuz-Bozdogan and Bozdogan (2009), by evaluating the percentage of drift up to $5 \mathrm{~m}$ from the treated area, also observed that the drift from all nozzles was underestimated by "German model" at $1 \mathrm{~m}$ from the treated area, which is in accordance to the results found in the present study.

\section{CONCLUSIONS}

Drift from applications through non-air induction nozzles decreased exponentially as the downwind distance increased. Four drift prediction models, similar to the "Dutch model", were obtained from applications on commom bean crop, with an exponential trend of four parameters considering the $90^{\text {th }}$ percentile, all with adjustments above $99 \%$. The coefficients of equation for bean crop culture vary from 6.7700 to $30.7647\left(\mathrm{~A}_{0}\right),-0.4949$ to $-0.5943\left(\mathrm{~B}_{0}\right)$, 0.5482 to $1.8278\left(\mathrm{~A}_{1}\right)$, and -0.0046 to $-0.0347\left(\mathrm{~B}_{1}\right)$. An effective solution to reduce the drift is increase the droplet size, especially in regions closer to the bean crop.

It is suggested to use the estimated drift models from this study for each nozzle type in drift prediction evaluations on bean crops under brazilian weather conditions.

\section{ACKNOWLEDGEMENTS}

The authors wish to thank the National Council of Scientific and Technological Development (CNPq) and the Research Foundation of the State of Minas Gerais (Fapemig) for their financial support.

\section{REFERENCES}

ALVES, G. S.; CUNHA, J. P. A. R.; PALLADINI, L. A. Seleção de traçadores para estudos de eficiência das aplicações de produtos fitossanitários. Planta Daninha. 32(4):861-870, 2014.

ARVIDSSON, T.; BERGSTRÖM, L.; KREUGER, J. Spray drift as influenced by meteorological and technical factors. Pesticide Management Science. 67(5):586-598, 2011.

BAETENS, K. et al. Predicting drift from field spraying by means of a 3D computational fluid dynamics model. Computers and Electronics in Agriculture. 56(2):161-173, 2007.

COMPANHIA NACIONAL DE ABASTECIMENTO - CONAB. Acompanhamento da safra brasileira: grãos. Safra 2014/15, Brasília, 2(5):117p. 2015.

DE SCHAMPHELEIRE, M.; SPANOGHE, P.; SONCKC, S. Risk assessment of pesticide spray drift damage in Belgium. Crop Protection. 26(4):602-611, 2007. 
FERNANDEZ, F.; GEPTS, P.; LOPES, M. Etapas de desarrollo de la planta de frijol (Phaseolus vulgaris L.). Cali: Centro Internacional de Agricultura Tropical, 1986. 34p.

FERREIRA, D. F. Sisvar: A computer statistical analysis system. Ciência e Agrotecnologia. 35(6):1039-1042, 2011.

GANZELMEIER, H. et al. Studies on the spray drift of plant protection products. Results of a test program carried out throughout the Federal Republic of Germany. Berlin: Federal Biological Research Center for Agriculture and Forestry, 1995. 111p.

GIL, E. et al. Determination of drift potential of different flat fan nozzles on a boom sprayer using a test bench. Crop Protection. 56:58-68, 2014.

HILZ, E.; VERMEER, A. W. P. Spray drift review: The extent to which a formulation can contribute to spray drift reduction. Crop Protection. 44:75-83, 2013.

HOLTERMAN, H. J.; VAN ZANDE, J. C. de. IMAG Drift Calculator v1.1 - User manual. IMAG Draft Report, 2003, 39 p.

INTERNATIONAL ORGANIZATION FOR STANDARDIZATION ISO. Equipment for crop protection - Methods for field measurement of spray drift. Geneva: ISO, 2005. 22 p. ISO/ FDIS 22866.

JONG, F. M. W.; SNOO, G. R.; ZANDE, J. C. Estimated nationwide effects of pesticide spray drift on terrestrial habitats in the Netherlands. Journal of Environmental Management. 86(4):721-730, 2008.

KASIOTIS, K. M. et al. Spray drift reduction under Southern European conditions: A pilot study in the Ecopest Project in Greece. The Science of the Total Environment. 479480:132-137, 2014.

MASKI, D.; DURAIRAJ. D. Effects of charging voltage, application speed, target height, and orientation upon charged spray deposition on leaf abaxial and adaxial surfaces. Crop Protection. 29(2):134-141, 2010.

MINISTÉRIO DA AGRICULTURA, PECUÁRIA E ABASTECIMENTO - MAPA. Ministério da Agricultura. Feijão. 2015. Available in: http://www.agricultura.gov.br/vegetal/culturas/feijao. Access in: February, 16, 2015.

MATTHEWS, G. A.; HAMEY, P. Y. Exposure of bystanders to pesticides. Pesticide Outlook. 14(5):210-212, 2003.
NUYTTENS, D. et al. Comparison between indirect and direct spray drift assessment methods. Biosystems Engineering. 105(1):2-12, 2010.

NUYTTENS, D. et al. Drift from field crop sprayers using an integrated approach: Results of a five year study. Transactions of the ASABE. 54(2):403-408, 2011.

NUYTTENS, D. et al. The influence of operator controlled variables on spray drift from field crop sprayers. Transactions of the ASABE. 50(4):1129-1140, 2007.

PEEL, M. C.; FINLAYSON, B. L.; MCMAHON, T. A. Updated world map of the Köppen-Geiger climate classification. Hydrology and Earth System Sciences Discussions. 11:1633-1644, 2007.

RAUTMANN, D.; STRELOKE, M.; WINKLER, R. New basic drift values inthe authorisation procedure for plant protection products. In: FORSTER, R.; STRELOKE, M. (Eds.), Workshop on Risk Assessment and Risk Mitigation Measures in the Context of the Authorization of Plant Protection Products (WORMM), Mitt. Biol. Bundesanst. Land-Forstwirtsch, Berlin-Dahlem, Heft 381, 133-141, 2001.

SCRAMIN, S. et al. Avaliação de bicos de pulverização de agrotóxicos na cultura do algodão. Revista de Ecotoxicologia e Meio Ambiente.12:43-50, 2002.

SPSS Inc. Released. SPSS Statistics for Windows, Version 22.0. Chicago: SPSS Inc. 2012.

TSAI, M. Y. et al. The Washington aerial spray drift study: Modeling pesticide spray drift deposition from an aerial application. Atmospheric Environment. 39(33):6194-6203, 2005.

VAN DE ZANDE, J. C. et al. Effect of width of spray-free buffer zones, nozzle type and air assistance on spray drift. Aspects of Applied Biology. 99:255-263, 2010.

VERCRUYSSE, F.; STEURBAUT, W. POCER, the pesticide occupational and environmental risk indicator. Crop Protection. 21:307-315, 2002.

WATSON, D. J. Comparative physiological studies on the growth of field crops. I - Variation in net assimilation rate and leaf area between species and varieties, and within and between years. Annals of Botany. 11(44):41-76, 1947.

YARPUZ-BOZDOGAN, N.; BOZDOGAN, A. M. Comparisons of field and model percentage drift using different types of hydraulic nozzles in pesticide applications. Internacional Journal Environmental ScienceTechnology. 6(2):191-196, 2009. 